\title{
Apple value chain analysis in two mountainous districts in Nepal
}

\author{
Prachanda Khadka • Svein Øivind Solberg*
}

Faculty of Applied Ecology, Agriculture Sciences and Biotechnology, Inland Norway University of Applied Sciences, P.O. Box 400, 2418 Elverum, Norway.

${ }^{*}$ Corresponding author. E-mail: svein.solberg@inn.no

Accepted 10 $0^{\text {th }}$ December, 2019.

\begin{abstract}
Apple (Malus pumila Mill.) is a popular temperate climate fruit but can grow at high altitudes in the subtropics where it can be an opportunity crop for small-scale farmers, amongst others in the Himalayan valleys and hillsides. This research was conducted to examine constraints and prospects of apple farming and marketing from remote parts of Nepal. The material included interviews of 60 farmers and among the selected farmers, apple contributed to about half of the household income and benefit-cost analysis showed a ratio of two, which means the farm business should be profitable, and this accounted for both regions. Labour was the single most important cost factor, contributing to $60-70 \%$ of the production costs. The difference between retail price and producer's price was high in both districts (around 100 $\mathrm{Rs} / \mathrm{kg}$ ), which means a relatively low producer's share. Pests and diseases were key problems in the production but also access to improved varieties and lack of post-harvest facilities was highlighted as important constrains. Key value-chain actors were mapped and the marketing system included several levels of traders. A simplified system with producer cooperatives was discussed to increase farm-gate prices and reduce consumer prices. Better coordination of actors in research and development was lifted as local engagements in projects.
\end{abstract}

Keywords: Benefit-cost analysis, gross return, Malus pumila, production costs, value chain.

\section{INTRODUCTION}

FAO (2014) has highlighted a sound ecology, a viable economy and a responsible society as three dimensions of sustainability in agriculture. One can find much literature on the ecological aspect of sustainability but less on economy and society. Ikerd (1997) discussed the nature of humans being able to make purposeful and self-conscious actions, which affects intervention but not necessarily sustainability. Understanding economy and society is therefore essential in developing agriculture. According to Awasthi (2007), agricultural marketing starts at the farm, when a farmer plans for a production. Thus, marketing can be seen as a flow (Kohls and Uhl, 1990; Mohy-ud-Din and Badar, 2011) where each step add value to the goods in terms of time, place and farm utilities (Pokhrel, 2011). A value chain describes such activities and the stakeholders involved in bringing a product or a service through the different phases from production and delivery to the final consumers (Kaplinsky and Morris, 2000). Mapping activities and stakeholders can be a useful tool in identifying bottlenecks with the aim to develop the chain.

On a global scale, apple (Malus pumila Mill.) production exceeds 89 million tons a year and is grown on more than 5 million hectors (FAO, 2016). It is a ubiquitous temperate fruit suited also for the Himalayan region. Nepal's apple production is around 5.6 Mt a year and with an average productivity of $7.3 \mathrm{Mt} / \mathrm{ha}$ (MoAD, 2015/16; MoALC, 2016/17). Apple is a high value cash crops envisaged by Government of Nepal for agricultural development in the mountainous rural areas (Atreya and Kafle, 2016). It is rich in nutrients, especially in vitamin C, but is bulky of nature with a relatively limited shelf life 
(Boyer and Liu 2004). Fruits are mostly consumed fresh but some is processed into juice, dried apple slices and other products. Remote areas in Himalaya have by default a tough topography, the production units here are small and they are usually isolated from bigger market places with little access to infrastructures such as road, irrigation, and storage facilities (SNV Nepal, 2011). Apple production in Nepal is increasing but at a very slow rate and mostly due to increased area under cultivation and not increased productivity (Thapa et al., 2004). Another issue is the seasonal nature that causes abundant domestic production in short peak seasons and low domestic supply at other times of the year. Beside this, a total of 83,000 metric tons of fresh apple was imported to Nepal in fiscal year 2016/17 (MoALC, 2016/17). Thus, this paper has tried to examine the contribution of apple farming in the household economy with the objectives to identify the actors of the apple value chains and analyse the structure following Kaplinsky and Morris (2001). In addition, we aimed to analyse the price, cost, margins and profit sharing at each stage of the apple value chains and to identify the prospects and problems associated with the apple production and trading in Nepal.

\section{MATERIALS AND METHODS}

\section{Selection of study area}

More than 50 districts in Nepal are now growing apple, among which 12 are major and in mountainous regions. We selected the most important area, Jumla district $(3,100 \mathrm{ha})$, and the third most important area, Mustang district (957 ha) (MoAD, 2015/16).

Mustang district lies in province no. 4 and is known as the district across the mountains as it lies in the TransHimalayan region in the North of Central Greater Himalaya named as Annapurna and Dhaulagiri ranges and surrounded by Tibet Autonomous Region of China. Besides apple, Mustang is also famous for its scenery and has good position in tourism, which adds up a market potential for apples produced in this district. It is located in between $28^{\circ} 33^{\prime}$ to $29^{\circ} 19^{\prime} \mathrm{N}$ and $83^{\circ} 28^{\prime}$ to $84^{\circ} 14^{\prime} \mathrm{E}$ and the altitude ranges from 1640 to $7061 \mathrm{~m}$ above sea level. Mustang receives an average of less than $260 \mathrm{~mm}$ rainfall annually as recorded in lower Mustang, Jomsom. This district experiences an average minimum temperature of $-2.7^{\circ} \mathrm{C}$ in the winter and an average maximum temperature of $23.1^{\circ} \mathrm{C}$ in the summer. It covers an area of 3563.21 sq. $\mathrm{km}$ of which $57.7 \%$ is barren land, $30.26 \%$ is grassland, $2.91 \%$ forest, $1.6 \%$ cultivated land and rest others (KC et al., 2014). The registered apple area is around 1000 ha with a productivity of around 15 $\mathrm{mt} / \mathrm{ha}$.

Jumla district, situated in province no. 6 , is one of the most poorly developed districts of Nepal. It lies in the western part of the country, $25^{\circ} 58^{\prime}$ to $29 \mathrm{~N}$ and $81^{\circ} 51^{\prime}$ to
82³5' E with elevation from 915 to $4679 \mathrm{~m}$ above sea level. This district experiences a variation in temperature from 18 to $30^{\circ} \mathrm{C}$ in the summer and -14 to $8^{\circ} \mathrm{C}$ in winter and annual average rainfall is around $1300 \mathrm{~mm}$. The main economic activity of Jumla is agriculture where most important cereal crops are paddy rice, maize, wheat and barley, whereas apple, potato, beans, oil seed and herbal products are the major cash crops (Sapkota et al., 2010; Paudel, 2011). Organic Certification Nepal has certified Jumla as an organic district. With a total area of 2531 sq.km, 39,486 ha is cultivable land. Though lying in high altitude, Jumla has favourable condition for apple production. Total area under apple orchard in Jumla was 3100 ha, of which only 850 ha was the productive area (MoAD, 2015/16). The productivity of apple in was around $3.7 \mathrm{mt} / \mathrm{ha}$. Similarly, other fruit crops grown in Jumla were apricot, walnut, peach, pear, plum. The economy of most of the farmers in these two districts is shaped by the apple production. The total population of Jumla was 45,089 with a sex ratio of 102 , and a dependency ratio (population aged below 15 and above 59 over the population aged between 15 and 59) of 88.4 (CBS, 2014a). The total population of Mustang was 13,452 with a sex ratio of 112 and a dependency ratio at 52.1 (CBS, 2014b). This means that there is a higher surplus of men in Mustang compared to Jumla but also that a lower proportion of the population is as children or elder people. For Nepal as a whole, the sex ratio is 94.2 and the dependency ratio 66.0 (CBS, 2014c).

\section{Sampling procedure and selection of respondent}

The surveys were conducted during the month of December 2017 and January 2018. Semi-structured questionnaires were used to collect the primary data from farmers/households $(\mathrm{HH})$ and the various other actors of the value chain. Lists of producers were obtained from the respective District Agriculture Development Office (DADO) of each districts. After discussion with agriculture officers and local key informants, 30 apple growers/households were selected from each districts. Careful attention was paid to include producers from various wealth categories, farm size and ethnic groups. In addition, other actors of the value chain were interviewed For Jumla district the interviews included 15 consumers and 12 wholesalers/retailers, while for Mustang district the interviews included another 15 consumers and 8 wholesalers/retailers. Focus Group Discussion (FGD) and field observation was used to verify or add new information. Reports from District Agriculture Development Office (DADO) of Jumla and Mustang district, High Value Agriculture Project in Hill and Mountain Areas (HVAP), Nepal Agriculture Research Council (NARC), Ministry of Agriculture and Cooperatives (MoAC), Central Bureau of Statistics (CBS), SNV Nepal and USAID Nepal were reviewed. 
Table 1. Overview of the survey data from Mustang and Jumla districts with more information on the farmer/household $(\mathrm{HH})$ respondents.

\begin{tabular}{|c|c|c|}
\hline Parameter & Mustang district & Jumla district \\
\hline Number of farmers/households $(\mathrm{HH})$ interviewed & 30 & 30 \\
\hline Number of consumers interviewed & 15 & 15 \\
\hline Number of traders/retailers interviewed & 8 & 12 \\
\hline \multicolumn{3}{|l|}{ Gender of the $\mathrm{HH}$ respondents } \\
\hline Male (\%) & 57 & 63 \\
\hline Female (\%) & 43 & 37 \\
\hline Average family size of the $\mathrm{HH}$ respondents & 5.1 & 5.8 \\
\hline \multicolumn{3}{|l|}{ Ethnic composition of the $\mathrm{HH}$ respondents } \\
\hline Brahmin (\%) & 0 & 13 \\
\hline Chhetri (\%) & 0 & 64 \\
\hline Janajati $(\%)$ & 80 & 10 \\
\hline Dalit (\%) & 20 & 13 \\
\hline \multicolumn{3}{|l|}{ Household income of the $\mathrm{HH}$ respondents } \\
\hline From apple farming (\%) & 68 & 45 \\
\hline From others sources (\%) & 32 & 55 \\
\hline \multicolumn{3}{|l|}{ Cost of apple production } \\
\hline Labour (Rs '000' per Ropani* \pm SE) & $16.8 \pm 1.4$ & $4.9 \pm 0.5$ \\
\hline Fertilizer (Rs ‘000’ per Ropani` \pm SE) & $3.0 \pm 0.2$ & $1.1 \pm 0.1$ \\
\hline Plant protection (Rs ‘000’ per Ropani \pm SE) & $2.1 \pm 0.1$ & $0.7 \pm 0.1$ \\
\hline Farm equipment (Rs '000' per Ropani* \pm SE) & $2.6 \pm 0.2$ & $0.9 \pm 0.1$ \\
\hline Total costs of apple production (Rs ‘000’ per Ropani \pm SE) & $24.5 \pm 1.7$ & $7.7 \pm 0.7$ \\
\hline Total costs of apple production (in Rs/kg $\pm \mathrm{SE}$ ) & $47.2 \pm 2.6$ & $19.5 \pm 1.3$ \\
\hline Benefit cost ratio & 2.0 & 2.4 \\
\hline Farm gate price $(\mathrm{Rs} / \mathrm{kg})$ & 84.7 & 43.0 \\
\hline Retail price (Rs/kg) & 180.0 & 150.0 \\
\hline Marketing margin $(\mathrm{Rs} / \mathrm{kg})$ & 95.3 & 107.0 \\
\hline Producers' share (in \%) & 47 & 29 \\
\hline
\end{tabular}

*One ropani is equal to $509 \mathrm{~m}^{2}$, standard error of means are given as $\pm \mathrm{SE}$.

\section{Data analysis}

An overview of the data collection is provided in Table 1. Prior to analysis, values were coded and entered into Microsoft Excel for Mac, Version 1526 (160910), with the formulas for averages, standard error of mean and regression analysis. Information related to the cost of apple production, marketing system, marketing channel, contribution of apple to household income and issues related to production and marketing were obtained from the farmers survey. Similarly, information from traders and consumers were used for the marketing aspect as well as quality of the produce. Key informant interview was conducted with the agriculture officers of the respective districts for the information about the production and marketing situation of apples. For sociodemographic and farm characteristics, descriptive statistical tools such as frequencies, percentages, means, standard deviations and standard errors were used. Different variables such as family size, gender, occupation, land holding were parameters of interest.

Economic analysis included value chain mapping and analysis of production cost, gross margin, factors affecting gross margin, marketing margin, producers' 
share, and benefit-cost ratio calculations. Initial orchard establishment is a fixed cost but only variable cost items were considered in our calculations. Variable costs included costs for labour, manure/fertilizers, pesticides and farm equipment. Since most of small-scale, rural farmers in Nepal seldom have written records on their costs and income, it was very difficult to get detailed figures. Moreover, they apply their own farmyard manure as organic manure to the farm and they use themselves as main labour. Nearly none of the targeted farmers kept records. Thus, the cost of labour was calculated by multiplying the man-day spent in the farm for intercultivation in orchard, fetching and applying the manure, fertilizer and pesticides, training and pruning of apple tree and harvesting and marketing (wherever applicable) with the current basic wage per day of the country (Rs 395 per man-day). The cost of fertilizers from farmers' own farm yard pit and the cost of production of organic pesticides as well as the chemical fertilizers and pesticides bought from the market (for non-organic growers) was considered as the cost of fertilizers and insect/pesticides respectively for each district. Cost of farm equipment was the price paid for the different tools and equipment bought in the same year. Variable costs and income from apple production was analysed by regression analysis as per the protocol of Cobb-Douglas production function.

\section{Gross return and gross margin calculation}

Gross return $(\mathrm{Y})$ was the amount of money per ropani received by the farmer by selling apple at farm gate price. It was calculated by yield of apple per ropani multiplying with the farm gate price of the farmer. Labor cost $\left(X_{1}\right)$ was the product of national per day wage and the total human labour spent on the apple orchard of 1 ropani. The direct cost for hired labour and the opportunity cost for the family labour spent on the orchard was calculated as the labour cost. It included the labour for manuring, irrigating, training, pruning of trees, applying plant protection in the orchard, harvesting of apples and other activities requiring human labour. Fertilizer cost $\left(X_{2}\right)$ was the cost of fertilizer and was calculated from the direct expenditure on the chemical fertilizers and imputed cost of own farmyard manure applied per ropani. Plant protection cost $\left(\mathrm{X}_{3}\right)$ was the plant protection cost and was calculated from the direct expenditure on the chemical and organic pesticides and the imputed cost for preparation of homemade organic pesticides. Farm equipment cost $\left(X_{4}\right)$ was the cost of farm equipment and was calculated from the direct expenditure on different farm equipment purchased in the year between the last two consecutive harvesting of apple.

Gross margin was calculated as the difference between the gross return and the variable cost, where Gross return $=$ Quantity of product sold $(\mathrm{kg}) \times$ Unit price of product $(\mathrm{Rs} / \mathrm{kg})$ and total variable cost $=$ sum of cost of all variable inputs. Gross margin analysis is a quick and easy method to analyse a farm business since it offers a direct means to compare the technical efficiency of the business (Upton, 1964). Benefit cost analysis is the benefit or return of a farm business relative to its cost. Benefit cost ratio is the ratio of total revenue and total cost. In our study, the total revenue means income and total cost means variable cost (Luitel, 2017). The benefit cost ratio $=$ Gross income divided by total costs. If the ratio is less than 1 , then the farm business certainly can be considered as unprofitable. The difference between farm-gate price received by the producer and the price paid by the consumers is known as marketing margin, also known as price spread(Amgai et al., 2015), where Marketing margin $=$ Retail price minus Farm gate price . The ratio between farm-gate price and retail price is known as producer's share and was expressed in percentage.

\section{Estimation of productivity}

Cobb-Douglas production function was used to estimate the productivity (Kopp and Smith, 1980; Idiong, 2007). The Cobb-Douglas function is widely used in many empirical studies, mostly dealing with the study about developing country agriculture (Xu and Jeffrey, 1998; Idiong, 2007; Sarker et al., 2018). The specified CobbDouglas production function was; $\mathrm{Y}=$ $\alpha X_{1}{ }^{b 1} X_{2}{ }^{b 2} \ldots \ldots . . . X_{n}{ }^{b n}$, where $Y$ was the dependent variable and $X_{1}$ to $X_{n}$ were the explanatory ones. Similarly, $b_{1}$ to $b_{n}$ were the factors of respective production parameters. This function was then converted to logarithmic form in order to solve by least square method as follows; $\log Y=\log \alpha+b_{1} \log X_{1}+\ldots \ldots .+$ $b_{n} \log X_{n}$ where $Y=$ Gross return (Rs/Ropani), $X 1$ = labour cost (Rs/Ropani), $\mathrm{X} 2$ = Fertilizer cost (Rs/Ropani), $\mathrm{X} 3=$ Plant protection cost (Rs/Ropani), X4 = Cost of buying farm equipment (Rs/Ropani), and $\alpha, b_{(1-4)}=$ coefficients.

The total farm income from apple was calculated and was compared with the total income of the household. The income from apple was expressed in share of the total household income to analyse the contribution of apple in household economy.

\section{Mapping of value chain analysis}

Value chain shows the major actors and activities involved from production to the marketing and consumption in a sequential manner. Value addition in apple occurs in each step of the chain. From the study, the information on major actors and their activities along the marketing channel followed was collected and the value chain was mapped along with the analysis of price spread at each step.

From the qualitative data, indexing was done. Indexing 
was done for the analysis of producer's perception on the production and marketing problems of apple. Farmers' perception about the problems was ranked by using fivepoint scale of problem that is from highly problematic to highly non problematic. 1 represented for the highly problematic issue, 3 for neutral to the issue and 5 for highly non problematic issue. Then the priority ranking was done and a reasonable decision was made.

The following formula was used to find the index for intensity of various problems; $I_{\text {prob }}=\sum \frac{S i f i}{N}$ where, $I_{\text {prob }}=$ index of problem, $\Sigma=$ Summation, $\mathrm{Si}=$ Scale value at ith intensity, $\mathrm{fi}=$ Frequency of ith response, and $\mathrm{N}=$ Total number of observations.

\section{RESULTS AND DISCUSSION}

\section{Socio-demographic patterns}

Most of the respondents replied they were household heads and there was a slight overweight of men in our survey, $57 \%$ in Mustang and $63 \%$ in Jumla. The average family sizes of the respondents were 5.1 persons in Mustang and 5.8 in Jumla. According to official sources, averages are 4.0 and 5.6 persons per family in the two districts (CBS, 2014c). In both districts, household members were engaged in different kind of farm and offfarm activities, this to support the household needs. The activities included cultivation of other crops than apple, other businesses or off-farm labour or services. The respondents' families from Mustang were in average found to generate $68 \%$ of their total income from apple whereas the number from Jumla was $45 \%$. This revealed the significance of apple for these rural farmers but also the potential that exist in further improvement of apple cultivation and marketing.

\section{Costs and gross margin}

For overviewing the costs involved in apple production, variable costs incurred in the orchard in the year 2017 were considered. The labour costs were the highest among all variable cost in both the districts $(68 \%$ for Mustang and $64 \%$ for Jumla). Costs of fertilizer followed with the share of $12 \%$ in Mustang and $14 \%$ in Jumla, and plant protection and farm equipment with another 9-11\% each in both districts. Table 1 shows the details of the cost of production of apple, calculated per ropani, which is Nepalese area unit, or $509 \mathrm{~m}^{2}$. The total cost of production of apple was clearly higher in Mustang than in Jumla, both the total costs and costs per $\mathrm{kg}$ produced apple.

The gross margin was also higher in Mustang than in Jumla, $20.86 \pm 2.11$ and $10.26 \pm 1.5$, respectively (calculated in Rs per ropani, see explanation below). Market access could explain at least some of the difference. Jumla is far from the bigger market and the district was connected with a road first time in April 2007 (Gurung, 2016). The road has been blocked several timed due to landslides and there are various part very unsafe to travel. In addition, the consumer survey showed higher quality in apples from Mustang that in Jumla.

\section{Benefit-cost analysis}

A benefit-cost ratio provides a tool to judge the overall profitability of a business. We calculated the benefit-cost ratio of Mustang and Jumla district to 1.98 and 2.44, respectively and apple cultivation was found highly profitable in both districts. During the study, it was noticed that different government and non-government organizations were working to develop the apple cultivation sector. In general, benefit-cost ratio is known to be higher for fruits than for cereals and vegetables in the highlands of Nepal (Bhandari and Aryal, 2014/15). AP \& MDD (2017) reported a benefit-cost ratio of apple orchard in Mustang from 1.11 at the fifth year after orchard establishment to maximum 2.29 at the ninth year, with a decreasing ratio thereafter. In Jumla, the same authors reported a ratio from 1.13 at the fifth year and a maximum at 1.93 in the seventh year. Thereafter the ratio was decreasing as the returns of the fruits from the old tree decreases (AP \& MDD, 2017). From India, increasing returns are reported due to scale of apple production with best returns at the largest farms (Ali at el., 2019).

\section{Marketing system, marketing margin and producer's share}

Traders mostly collected the Jumla apples, and these traders can be a large farmer or just a local village trader. The trader then transported the apple to the wholesaler in Surkhet district or to Nepalgunj in the Terai (lowland of Nepal). The wholesalers sold the apples to the retailers of respective district and the bicycle vendors who sell fruits and vegetables door to door in the settlements and at the roadside of the market. The consumers get their Jumla apple from these retailers and the bicycle vendors. The District Cooperative Union and Organic multipurpose cooperative made contract with the farmers prior to the harvesting season, collected the apple from the big and small producers, and marketed the collection to wholesalers based in Kathmandu, Surkhet and Nepalgunj. The apple producers in Jumla also sold some of their fruits at the market of the district headquarter Khalanga and at the airport gate of the Jumla airport. Some of the produce from Jumla supplied the local processing industries, and after being processed to dried apple, juice and apple alcohol, it was sold to the retail shops in Jumla bazar and then to consumers, mostly tourists from 'Jumla Kosheli Ghar'. In Mustang, the 
Table 2. Coefficient and parameter estimates from regression analysis of the gross return in apple production in Mustang and Jumla districts.

\begin{tabular}{lcccccccc}
\hline & \multicolumn{2}{c}{ Coefficients } & & \multicolumn{2}{c}{ T value } & & \multicolumn{2}{c}{ P value } \\
\cline { 2 - 3 } & Mustang & Jumla & & Mustang & Jumla & & Mustang & Jumla \\
\hline Constant & 3.82 & 4.04 & & 3.75 & 3.49 & & $\mathbf{0 . 0 0 0 9}$ & $\mathbf{0 . 0 0 1 8}$ \\
Log Labor cost $\left(X_{1}\right)$ & 0.03 & 0.86 & & 0.23 & 3.98 & & 0.8222 & $\mathbf{0 . 0 0 0 5}$ \\
Log Fertilizer cost $\left(X_{2}\right)$ & 0.34 & -0.62 & & 1.52 & -2.33 & & 0.1408 & $\mathbf{0 . 0 2 8 5}$ \\
Log Plant protection cost $\left(X_{3}\right)$ & 0.70 & 0.37 & & 3.06 & 2.00 & & $\mathbf{0 . 0 0 5 3}$ & 0.0565 \\
Log Farm equipment $\left(X_{4}\right)$ & -0.19 & 0.04 & & -2.14 & 0.68 & & $\mathbf{0 . 0 4 2 4}$ & 0.5025 \\
\hline
\end{tabular}

Significant $P$ values in bold.

marketing system looked somewhat differently. Mustang is a very popular destination for tourists and during the harvesting season farmers themselves sold apple in the Jomsom bazar directly. Another market channel was individual, large contractors who make agreements with farmer prior to harvesting and these contractors then sold the apples to the wholesalers in Beni (Myagdi district), Baglung, Pokhara, Chitwan and Kathmandu. Retailer shops and bicycle vendors bought apples from these wholesalers and finally sold the fruits to the consumers. Throughout Nepal, Mustang apples are very popular for its quality. Some of the apples in Mustang were collected by the Marpha Horticultural Farm and processed into various apple products, mainly an alcoholic beverage (called "Brandy"), or into dried apple slices. These processed products were sold in Jomsom and Marpha, often to tourists, but also to retail shops and supermarket in Pokhara and Kathmandu district.

Farm-gate price in Mustang was Rs 84.67 per kg. The transportation cost from Jomsom to Pokhara was Rs 7.50 per $\mathrm{kg}$. The wholesale price in Pokhara was Rs 140 per $\mathrm{kg}$ and the retailers sold the apple at Rs 180 per $\mathrm{kg}$. Similarly, the farm-gate price in Jumla district was Rs 43 per $\mathrm{kg}$, transportation cost from Jumla to Nepalgunj (by road) was Rs 9 per $\mathrm{kg}$, while wholesale price in Nepalgunj was Rs 100 per $\mathrm{kg}$ and retailers sold the apples to the consumers for Rs 150 per $\mathrm{kg}$. Thus, the marketing margin for Mustang apple and Jumla apple was Rs 95.33 per $\mathrm{kg}$ and Rs 107 per kg respectively. The producers from Mustang obtained on average $47 \%$ of the price paid for the apple whereas only $29 \%$ was the Jumla producer's share. The higher producer's share in Mustang district envisaged a better marketing efficiency than in Jumla district. Such efficiency is known to increase the welfare of both producer and consumer (Arndt et al., 2000). Increasing the market efficiency, especially in Jumla district, could attract more producers to market their products and have more economic gains. The presence of several middlemen, as detected in both districts, hinders a vertical linkage between producers and consumers, which could harm farmers in the long run (Luitel, 2017). Cooperative marketing has the potential to increase the bargaining power of farmers and also to reduce transportation cost and commission costs during marketing, as demonstrated in vegetables in Nepal (Niroja et al., 2015). Thus, such collaboration, if successful, could increase farmer's share and reduce costs for consumers.

\section{Productivity and resource use efficiency}

The coefficients and the estimated values of the surveyed parameters are shown in Table 2. For Mustang region, plant protection had a coefficient of 0.7 , which was highly significant $(1 \%$ alpha level, $P<0.001)$. This implies that increasing the expense for plant protection to control the prevalent disease and insect pest in apple orchard of Mustang district would increase the production and give higher income. Similarly, the regression coefficient for farm equipment bought in Mustang was -0.19 , which was also significant $(P<0.05)$. It implied that every $10 \%$ more sum spent on farm equipment would decrease the level of return by $1.9 \%$. The non-significant coefficients of labour and fertilizer in Mustang suggested that there is a balanced use of labour and fertilizer in these apple orchards. The econometric model thus obtained from the analysis to explain the production use efficiency was: $\log Y=3.82+0.03 X_{1}+0.34 X_{2}+0.7 X_{3}+(-0.19) X_{4}$. In Jumla district, the coefficient of the variable labour was $0.86(\mathrm{P}<0.01)$. Investing in labour by $10 \%$ to manage the orchard would increase the farm production and ultimately the total return would increase by $8.6 \%$. The significant value of coefficient of fertilizer cost in negative $(-0.62)$ at $5 \%$ level of significance, suggested that increasing the investment in fertilizer by $10 \%$ further would decrease the total return by $6.2 \%$. This might be due to the excessive addition of the fertilizer in the orchard, which would increase the expense but not the production. The coefficient of plant protection and farm equipment for orchard in Jumla was not significant. This also suggested that excessive money is being spent in plant protection and farm equipment in the apple orchard of Jumla. The econometric model to explain the production function efficiency for Jumla apple growers was: $\log Y=4.04+0.86 X_{1}+(-0.62) X_{2}+0.37 X_{3}+0.04 X_{4}$ 
Table 3. Farmers' perception on the intensity of problems in apple production given as index values and ranks in Mustang and Jumla districts.

\begin{tabular}{lccccc}
\hline \multirow{2}{*}{ Production problem } & \multicolumn{2}{c}{ Mustang } & & \multicolumn{2}{c}{ Jumla } \\
\cline { 2 - 3 } \cline { 5 - 6 } & Index value & Rank & & Index value & Rank \\
\hline Disease/insect and pest & 1.47 & $\mathrm{I}$ & & 1.5 & $\mathrm{I}$ \\
Planting material & 4.57 & $\mathrm{~V}$ & & 4.07 & $\mathrm{~V}$ \\
Irrigation & 4.43 & $\mathrm{IV}$ & & 2.8 & $\mathrm{II}$ \\
Technical knowledge & 4.37 & $\mathrm{III}$ & & 4.27 & $\mathrm{IV}$ \\
Loan facility & 2 & $\mathrm{II}$ & & 3.6 & $\mathrm{III}$ \\
Crop insurance & 0 & $\mathrm{~N} / \mathrm{A}$ & & 0 & $\mathrm{~N} / \mathrm{A}$ \\
\hline
\end{tabular}

\section{Key problems related to apple production}

Diseases and insect pests in the apple orchard was the most problematic issue for farmers from both the districts. The index value of disease insect and pest was 1.47 and 1.5 for Mustang and Jumla respectively. Lack of loan facility, lack of technical knowledge, lack of irrigation and lack of good quality planting material were the other top ranked constraints for the apple producer in Mustang district. Similarly, lack of irrigation, lack of loan facility, lack of technical knowhow and lack of good planting material was the order of problems in perception of Jumla's farmers. Farmers from both the districts were not acquainted with the crop insurance of their apple orchard. Table 3 shows the index value and ranking of problem according to the perception of farmers from the respective districts.

\section{Value chain mapping}

There were one agro-vet in Mustang and six in Jumla, providing pesticides and related inputs to apple farmers. There were five registered apple nurseries in Mustang and 33 in Jumla, in addition to more un-registered nurseries, the latter as per information from given by an agricultural officer. We found that the apple nurseries had no access to new and improved varieties. In both districts, Delicious varieties like Red, Royal and Golden Delicious were popular varieties. In addition, Chocolate, Jonathan, Macintosh and Richard varieties were produced. A few farmers in Mustang district had started to introduce Fuji apple varieties in their orchard. The harvesting season, from early August to late September, was the same in both districts, and there was a great supply of apples at that time of the year. Production of dried apple slices, ciders, jam and jelly, and apple brandy, a high alcoholic beverage, were done in both districts. Such products were prepared by RK apple distillery in Jumla and Marpha Horticultural Farm in Mustang in addition to a few small-scale farmers. In Jumla, there was one governmental processing centre, Jumla Apple Processing Center (JAPC), running under Ministry of Agriculture and Livestock Development
(MoALD), doing the same. Here, farmer could bring all their ingredients and use the machinery/equipment for processing their apple into desired forms like dried apple slices or apple jam/jelly. Most of these products were consumed in Jumla district from local gift shops, as the production was low. Local and district level traders were common in both districts. In Jumla, there were a few cooperatives, collecting apples form various farmers for trading to wholesalers. Some large-scale farmers also collect apples from surrounding farms and traded it to wholesalers. For Mustang apples, the Pokhara Agriculture Wholesale Market is an important market place, where apples are sold from local traders to wholesalers and retailers based on Pokhara, Chitwan and Kathmandu. In addition, Kalimati and Balkhu fruit and vegetable markets are important. Wholesalers at these markets buy apples from both Jumla and Mustang, as they import apples from India and China. Balkhu fruit wholesale market is a jointly owned wholesale market by GoN and the public. The majority of the retailers, like the different department stores, fruit and vegetable shops, and the bicycle vendors in the Kathmandu valley buy their apples from these wholesales markets.

Regarding value chain actors, the farmers indicated that the District Agriculture Development Office (DADO) has a lead role to transfer technology to farmers in both Mustang and Jumla. DADO were not only involved to providing technical assistance in production but they also have several other roles. They subsidize saplings to the poor and needy farmers when establishing apple orchard, give training on cultivation practice and orchard management, grafting and nursery production, and provides subsidies as per the rule of GoN, and they provide assistance to District Development Committee in formulating agriculture related plans and policies. A farmer from Patarashi-4, Jumla said that he got knowledge and training in pruning of apple trees, which has led to better production in terms of both quality and quantity. He also said that still many believe that pruning reduces apple production. Other important actors for farmers were the Horticulture Research Station in Pokhara and in Rajikot, both under Nepal Agricultural Research Council (NARC). Nepal Horticulture Promotion Centre (NHPC) is a national level NGO conducting 
programs for capacity building, amongst other for apple producers. Organic Certification Nepal (OCN) is the most popular organic certifying agency in Nepal. There are no government organic certifying body in Nepal, and amidst a few other private certifying bodies, OCN was the most popular. OCN also helped in training in growing apples organically. Ministry of Agriculture and Livestock Development (MOALD) is the central body of GoN responsible for the agriculture development of Nepal. It has several departments, directorates and projects related to development of apple farming in Nepal. Some of the relevant ones identified in this study were Department of Agriculture (DoA), the lead government organization for the development of agriculture in Nepal. Its broad objective was to achieve food security and alleviate poverty through transformation of agriculture in Nepal (DoA, n.d.). The implementing bodies of DoA are the Regional Directorates (RD) and the DADOs. These offices were mainly responsible for the extension services and transfer of technology to the farmers. Fruit Development Directorate (FDD) is the central technical body under DoA for the development of fruits, coffee, tea and ornamental crops in Nepal. It has its broad objective to increase the level of income of farmers by increasing the production and productivity through research and dissemination of improved technology. Agribusiness Promotion and Marketing Development Directorate (AP \& MDD) was the major government body responsible for agribusiness promotion and marketing of agricultural produce within the country through various wholesale and retail markets. Kalimati Fruits and Vegetable Market Development Board is the terminal wholesale market in Nepal. It facilitated the trade and marketing of various fruits and vegetables, including apple from Jumla and Mustang. It was regulating the prices of the commodity in value chain as much as possible. Pokhara Agriculture Wholesale Market was the wholesale market owned by GoN in Pokhara. It was facilitating the trade of apple from Mustang to Kathmandu, Pokhara and Narayanghad. District Chambers of Commerce and Industry (DCCl) is an organization of the shopkeepers and traders of the respective district. It was found that $\mathrm{DCCl}$ in Jumla was more active than in Mustang but they were both operating souvenir shops to sell the diversified apple products as dried apple slices, jam, and apple alcoholic beverages just near to the airport of respective districts. The president of Jumla Chamber of Commerce and Industry said that they have been facilitating the traders to conduct apple business with the wholesalers in Kathmandu and Narayanghad.

Among international organisations and projects, the High Value Agriculture Project in Hill and Mountain Areas (HVAP) was identified as important. This is a project jointly implemented by MoALD, SNV Netherlands Development Organization, Agro-Enterprise Centre (AEC), DADO/DLSO/DFO and local NGOs in the respective district. Specifically relevant for the apple value chain, the project support in capacity building of DADO Jumla and in various trainings for apple nursery owners and apple producers. World Vision International Nepal (WVIN) was supporting the organic certification of the apple orchards and in capacity building of Local Agricultural Resource Farmers (LARFs) and in local value chain development.

\section{Constraints and opportunities in the apple value chain}

On input supply, we identified that no official quality monitoring of saplings from nurseries was carried out by any government organization before selling. Furthermore, the nurseries had no access to newly improved varieties and produced saplings of old varieties only. Some nurseries (especially in Jumla) were unaware of the varieties they were raising. Some were also unaware of the need for another pollinating variety for improving the yields. The permitted bio-fertilizer and bio-pesticides were not adequate in both the districts and the farmers complained about the timely delivery of the fertilizers and other remedies through the agro-vets.

On production, farmers from both the districts complained about apple disease and pests and saw this as a major problem. Specific diseases mentioned were powdery mildew, apple scab, crown gall and pink diseases, and this accounted for loss of revenue in both districts. Similarly, wooly aphids, San Jose scale, stem and root borer, and tent and slug caterpillar were common insect pests in both district. It is well known that especially the pests are highlighted as a major problem in apple production (Hussain et al., 2018). Poor orchard management was identified in both regions. In particular, there was a lack of knowledge and training on pruning of trees and fruit thinning. This had led to a poor quality of the fruits. Irrigation was another major problem in most of the orchards of Jumla district, though comparatively less in Mustang. Most of the farmers were found to harvest the fruits by shaking the trees, leading to deterioration of the fruits with bruises. Another issue during harvesting was that grading of fruits according to variety was not practiced, and most farmers had various varieties in the same orchard. The storage facility of apple was not adequate in both the districts, and this accounted both for farmers and traders. Farmers still practice the indigenous way of storing apple in ground floor or cellar storage with very small capacity and with high post-harvest losses. An interesting finding was that almost all respondents were unaware of the possibility of a crop insurance for their apple orchards, a system that has been established since long.

Regarding technology development and research, we could identify that indigenous knowledge of bio-pesticides represent an opportunity and could help the producers to minimize costs on input chemicals. Similarly, research in 
introducing new apple varieties is an issue for research and development. We also see opportunities in increasing the quality of compost manure and farmyard manure as a way to reduce the costs of input fertilizers. Knowledge on climate change adaptation of the farmers was minimal, like introducing late and early maturing trees to reduce the risks of crop failure. Regarding postharvest issues, some research had been conducted to examine the effect of packaging material during marketing (Paudyal, 2017; Subedi and Giri, 2017) but the effect was found to be poor or only led to decreased consumer preference in the market. Regarding organization and public management, different actors and projects were in operation to enhance the apple value chain in the target districts. Better coordination between the actors is an issue and local ownership to developed projects and inclusion of government bodies like DADO could be an opportunity to strengthen the management practice in the apple value chain. Better coordination has been lifted also in other studies, e.g. by Hardman et al. 2008 working with South African apple production systems.

On regulatory policy, we identified that there was no organic certification system from the GoN and that the popular organic certifying agency was OCN. Individual certification was however very expensive and group certification could be comparatively cheaper. The consumer awareness about organic products is increasing the willingness to pay for organic products in urban and semi-urban areas of Nepal are growing (Rai and Adhikari, 2016). Thus, development of national accreditation system could increase the market for organic produce benefitting rural people.

Regarding marketing and logistics, infrastructure is a key issue in Nepal. The roads in both districts are improving and could lead to better opportunity for marketing of the produce and could even stimulate export to other countries. We identified that traders rather than producers were involved in the pricing of apple and this would risk high consumer price and low producer's share. Low producer's share is not unique for Nepal. Recent apple value-chain analysis in Ethiopia has shown that growers retain only $19 \%$ of the value while traders retain more than $80 \%$ (Getahun et al., 2018). Attempts to fix the prices have been made at the Kalimati fruit and vegetables market but was not successful due to lack of market monitoring. Cooperative marketing could be an option to provide good producer's share for the apples. More study on marketing is needed to reduce the number of steps in the marketing channel.

\section{CONCLUSION}

For apple production, labour costs and pest and disease problems were identified as key challenges in both Jumla and Mustang districts. Furthermore, access to improved varieties and lack of post-harvest facilities were important constrains for the growers and their households. A value chain with several levels of traders and low producer's share was detected in both districts, however with some differences between Jumla and Mustang. A system with producer cooperatives could be an alternative. Furthermore, improved research and development but also coordination between actors would be of importance for future development in apple production in remote areas of Nepal.

\section{ACKNOWLEDGEMENT}

We like to thank Hans Christian Endrerud from Inland Norway University of Applied Sciences as well as Anup Nainabasti and Bharat Prasad Kandel from District Agriculture Development Office in Mustang and Jumla for their kind assistance in planning the survey. We also like to thank the local villagers and in particular Lokendra Rana, Deepak Khatri and Jit Bahadur for their hospitality and help during the fieldwork.

This research did not receive grants from funding agencies in the public, commercial, or not-for-profit sectors. The authors declare that there are no conflicts of interest. PK was the main investigator and SøS contributed with editing and writing.

\section{REFERENCES}

Ali J, Kachroo J, Bhat DJ, Rizvi SHE, Sharma BC (2019). Analysis of Resource use Efficiency in Apple Production on Outer Himalayan Range of Chenab Valley. Econ. Affairs. 64(1):69-76. doi:10.30954/0424-2513.1.2019.9.

Amgai S, Dutta JP, Regmi PP, Dangol DR (2015). Analysis of Marketing Practices of Apple in Mustang District of Nepal. Agric. Dev. J.p. 11.

AP \& MDD (2017). Costs of production and benefit cost analysis of fruit farming in Nepal 2073/74 (2016/17). In: Agriculture D o (Ed.). Agribusiness Promotion and Market Development Directorate.

Arndt C, Jensen HT, Robinson S, Tarp F (2000). Marketing margins and agricultural technology in Mozambique. The J. Dev. Stud. 37:121-137.

Atreya P, Kafle A (2016). Production practice, market and value chain study of organic apple of Jumla. J. Agric. Environ. 17:11-23.

Awasthi BD (2007). Relevance of market information system to environment protection. J. Agric. Environ. 8:46-54.

Bhandari NB, Aryal M (2014/15). Average cost of production and gross profit of fruit farming in Nepal 2071/072 (2014/15). In: Agriculture D o (Ed.). AP \& MDD, Market Research and Statistics Management Program.

Boyer J, Liu RH (2004). Apple phytochemicals and their health benefits. Nutr. J. 3(5):1-15.

CBS N (2014a). National popualation and housing census 2011 (Village Development Committee/Municipality) Jumla. In: Statistics C B o (Ed.), Kathmandu, Nepal.

CBS N (2014b). National popualation and housing census 2011 (Village Development Committee/Municipality) Mustang. In: Statistics C B o (Ed.), Kathmandu, Nepal.

CBS N (2014c). National population and housing census 2011 (Population projection 2011 - 2031). In: Statistics C B o (Ed.), Kathmandu, Nepal.

DoA (n.d.). Department of Agriculture, Ministry of Agriculture and Livestock Development, Government of Nepal.

FAO (2014). Building a common vision for sustainable food and 
agriculture: principles and approaches. FAO, Rome, Italy, p. 12.

FAO (2016). Statistical Database.

Gurung P (2016). Notes from Jumla bazaar. myRepública.

Getahun W, Tesfaye A, Mamo T, Ferede S (2018). Apple Value Chain Analysis in the Central Highlands of Ethiopia. Int. J. Agric. Innov. Res. 7(1):2319-1473.

Hardman P, Darroch M, Ortmann G (2008). Improving cooperation to make the South African fresh apple export value chain more competitive. J. Chain Network Sci. 2(1):61-72. https://doi.org/10.3920/JCNS2002.x018.

Hussain B, Buhroo AA, War AR, Sheerwani A (2018). Insect-Pest Complex and Integrated Pest Management on Apple in Jammu and Kashmir, India. In: Apple: Production and Value Chain Analysis. ISBN 9789351249214.

Idiong I (2007). Estimation of farm level technical efficiency in smallscale swamp rice production in cross river state of Nigeria: a stochastic frontier approach. World J. Agric. Sci. 3:653-658.

Ikerd J (1997). Understanding and managing the multi-dimensions of sustainable agriculture. Southern Region sustainable agriculture professional development program workshop, SARE regional training consortium, Gainesville, FL.

Kaplinsky R, Morris M (2000). A handbook for value chain research. University of Sussex, Institute of Development Studies.

KC K, Poudel KR, Paudel N, Pokharel RP, Koirala S (2014). Resource Mapping Report. District Development Committee, Mustang.

Kohls RL, Uhl JN (1990). Marketing of agricultural products. Macmillan Publishing Company.

Kopp RJ, Smith VK (1980). Frontier production function estimates for steam electric generation: A comparative analysis. Southern Econ. J. pp. 1049-1059.

Luitel G (2017). Value chain analysis of coffee production in central Nepal. Agricultural Economics.

MoAD (2015/16). Statistical information on Nepalese Agriculture. Monitoring Evaluation and Statistics Division, Singha Durbar, Kathmandu.
MoALC (2016/17). Statistical information on Nepalese agriculture. Ministry of Agriculture, Land Management and Cooperatives, Monitoring, Evaluation and Statistics Division, Agriculture Statistics Section, Singhadurbar, Kathmandu, Nepal.

Mohy-ud-Din Q, Badar H (2011). Marketing of agricultural products in Pakistan: theory \& practice. Higher Education Commission.

Niroja P, Mamoru I, Muto Y (2015). Marketing System of Agricultural Cooperatives in Nepal: A Case Studies of Janagarathi Vegetable and Fruit Producer Agriculture, Cooperative. Rev. Integr. Bus. Econ. Res. 4:337.

Paudel M (2011). Rice (Oryza sativa L) cultivation in the highest elevation of the world. Agron. J. Nepal 2:31-41.

Pokhrel CN (2011). Analysis of market chain of mandarin in Nepal: A case of Lamjung district.

Rai K, Adhikari R (2016). Organic agriculture: willingness to pay for organic vegetables in Kathmandu valley. Nepalese J. Agric. Sci. 14:43-49.

Sapkota S, Paudel MN, Thakur NS, Nepali MB, Neupane R (2010). Effect of climate change on rice production: a case of six VDCs in Jumla district. Nepal J. Sci. Technol. 11:57-62.

Sarker B, Majumder S, Sayem SM, Farid MS (2018). Gross Margin and Factor Analysis of Watermelon Production in Patuakhali District, Bangladesh.

SNV Nepal (2011). A value chain analysis of apple from Jumla. SNV Nepal, Kathmandu.

Thapa PK, Saraf D, Gaire KR (2004). Commodity case study: fruits. Implications of the WTO Membership on the Nepalese Agriculture.

Upton M (1964). A development of gross margin analysis. J. Agric. Econ. 16:111-117.

Xu X, Jeffrey SR (1998). Efficiency and technical progress in traditional and modern agriculture: evidence from rice production in China. Agric. Econ. 18:157-165.

http://www.sciencewebpublishing.net/jacr 